\title{
Inequality and the 2019 Presidential Election in Indonesia: Beyond Identity Politics
}

\author{
Wahyu Prasetyawan \\ UIN Syarif Hidayatullah Jakarta, Indonesia \\ E-mail: wprasetyawan@gmail.com
}

\section{JEL Classification:}

D30

D72

$\mathrm{H} 23$

P16

Received: 20 September 2021

Revised: 22 December 2021

Accepted: 29 December 2021

\begin{abstract}
This study intends to understand vote based on economic evaluation at the 2019 presidential election in which Joko Widodo was incumbent, and Prabowo was the challenger. This paper argues that the presidential election in 2019 is a political arena where the voters assess the incumbent government's economic policies, one of which is redistributive. Redistributive policies are understood as government policies intended to reduce the gap between the rich and poor people or inequality. This empirical study uses merged data from BPS, Bappenas, and the KPU. By employing a unique dataset, the originality of this study is located on the relevance of redistributive policies in political contestation. This study estimates the outcome of the presidential election using the ordinary least square (OLS) method. It points out that reducing inequality at the district level influenced the presidential election result. This paper stresses that the capability of the government to reduce inequality determines the result of the election.
\end{abstract}

\section{Keywords:}

presidential election, inequality, redistributive policies, democracy

\section{How to Cite:}

Prasetyawan, W. (2022). Inequality and the 2019 Presidential Election in Indonesia: Beyond Identitiy Politics. Signifikan: Jurnal Ilmu Ekonomi, 11(1), 1-16. https://doi.org/10.15408/sjie.v11i1.22540. 


\section{INTRODUCTION}

Two characteristics of the Indonesian economy have changed slowly over the last 20 years and lead us to question their relevance for presidential elections. First, there has been a stagnation in the average annual growth of the economy compared to the New Order administration. The average annual growth of the New Order was around $7.4 \%$. However, after the fall of the New Order administration, growth has been much slower, averaging around $5.4 \%$ from 2009 to 2017 (Sato, 2019).

Second, a rise in inequality (in expenditure terms) in the last 20 years. Besides inequality in terms of expenditure, there is wage inequality in Indonesia, as Widyanti (2018) argued, but this paper focuses on inequality in expenditure. In this paper, inequality refers to the one in expenditure. In 2014, Indonesia experienced a record high in inequality which reached 0.41 as measured by the Gini coefficient. Less than two decades from 1996 to 2010, average growth annually in household consumption for the rich had grown three times faster compared to those of the poorest ones. The consumption level of the poorest $60 \%$ of households grew below the mean, and growth for the poor was close to zero in real terms (World Bank, 2016). The trend of a more significant gap can be traced since 2010. By looking at the middle-income group, the country recorded an increase of middle class for $56.6 \%$ compared to that of in 2000 that reached $20 \%$ (Maipita \& Wahyudi, 2017). The middle-income group has grown at $10 \%$ annually since 2002 (World Bank 2016). This present paper has no space to discuss why inequality is increasing and how it is associated with the rise of the middle-class. ${ }^{1}$

This paper argues that the presidential election in 2019, as a democratic procedure, is a political arena where the voters assess the incumbent government's economic policies, one of which is redistributive. Here, redistributive policies are understood as government policies intended to reduce the gap between the rich and poor people, such as assistance to the poor in the form of rice subsidy, access to education and healthcare, and various social assistance to help the poor people. ${ }^{2}$ The Indonesian government introduced cash transfer, conditional cash transfer, and non-cash socialeconomic programs to move the poor from poverty. At this crucial point of the 2019 election, the voters judge whether the government meets their demand for redistribution of economic provision to reduce the gap between the rich and the poor people. This article explores that inequality, relative distribution expenditure, is still crucial in the election. The Joko Widodo (henceforth Jokowi) government, which was incumbent in the 2019 presidential election, adopted various redistributive policies to reduce rising inequality trends. Furthermore, this paper argues that the government adopted redistributive policies to respond to voters' demand for better access to basic provisions such as education and healthcare. The government adopted redistributive policies to

\footnotetext{
${ }^{1}$ World Bank. 2016. This report explains some sources of inequality, see p. 11

${ }^{2}$ Following discussion provided by Galasso, Vincenzo. 2017. Political Economics: Redistributive Policies. Milan: Bocconi University Press. Detailed discussion on redistributive policies is on chapter 5. He discusses progressive tax, but in this paper tax policies are not included
} 
gain legitimacy from the voters. In addition to that, the government adopted these policies to mitigate potential conflict that would have been arisen if the poor people had less access to education, the healthcare system, and other provisions. While this paper underlines the relevance economy, especially the government redistributive policies to reduce inequality, it is intended to supplement the existing opinion that the presidential election in 2019 was marred by identity politics (Pepinsky, 2019). This paper proposes an argument by emphasizing economic variables.

This study has three contributions to understanding inequality and democracy in Indonesia. First, democracy in Indonesia which had started after the fall of Suharto in 1997, ensued by the direct presidential election in 2004, gave way for contestation over policies. During the election in 2019, identity politics had been at play (Pepinsky, 2019). Therefore, the role of economic factors in 2019 presidential had been overlooked. While the argument about identity politics is valid, the 2019 election also revealed that economic issues, in this case, inequality, could serve as one of the determinants which decide the election outcome. Second, the government started to design and implement redistributive policies when it was aware that the gap between the rich and the poor people recorded a high point in 2014. Implementing a range of redistributive policies in Indonesia is not a new phenomenon as the New Order government had introduced them under Suharto. However, the economic and political situation after the economic crisis in 1997/98 had been somewhat different where the economic recovery process benefited the middle classes (Dartanto et al., 2020), which accounted for 20\% (World Bank, 2018). This data means that the economic recovery process had put the majority in the poor category, and this situation would steer to increased inequality. Therefore, the government devised various redistributive policies which are intended to assist the poor people to move out from poverty. If the poor people fail to join the middle class, which means a high level of inequality, a more polarized society may result (World Bank, 2018) and lead to social conflict (Tadjoeddin et al., 2020). Third, this analysis demonstrates that higher levels of inequality may improve political demand from most voters, providing compelling evidence that greater economic inequality would function democracy as many voters could be categorized in the low-income level. Therefore, as one of democracy parameters, the presidential election is obviously an arena where the voters assess the incumbent government, including in the economic domain.

Why does inequality matters in the Indonesian political economy context? Aspinall (2015) argues that Indonesian society has a strong ethos of egalitarianism and is therefore hostile to the social gap. He mentions that this attitude has roots in the Indonesian anti-colonial struggle's economic nationalist and socialist themes. In addition to that, the democratic government of Post-Suharto's Indonesia is unable to give benefits to the poor (Kawamura 2019). As far as 2014, inequality was a political issue for two reasons. First, in 2014 President Susilo Bambang Yudhoyono's decade in office was about to end. There were feelings of dissatisfaction with his leadership (Aspinal et al., 2015). Second, the 2014 presidential election was a contestation year, and voters look at the candidates they believe could address inequality. Inequality was experiencing an increase in Susilo 
Bambang Yudhoyono's decade rule. Prabowo employed a narrative that inequality in Indonesia results from a political system that benefits the rich. In 2017, two years before the presidential election, again Prabowo employed a similar strategy to use inequality as a central issue for the campaign (Muhtadi et al., 2019).

The discussion above reveals that inequalities have been a political issue in many elections that Prabowo used to gain votes. In his 2014 campaign, Prabowo claimed that the Indonesian government could not reduce the gap between the poor and the rich. He repeated this topic of inequality in the 2019 presidential election claimed that president Jokowi, the incumbent, failed to reduce the gap between the rich and the poor. Therefore, it is necessary to evaluate the inequality.

Figure 1. Inequality in Indonesia 2000-2020 as measured by Gini in terms of expenditure

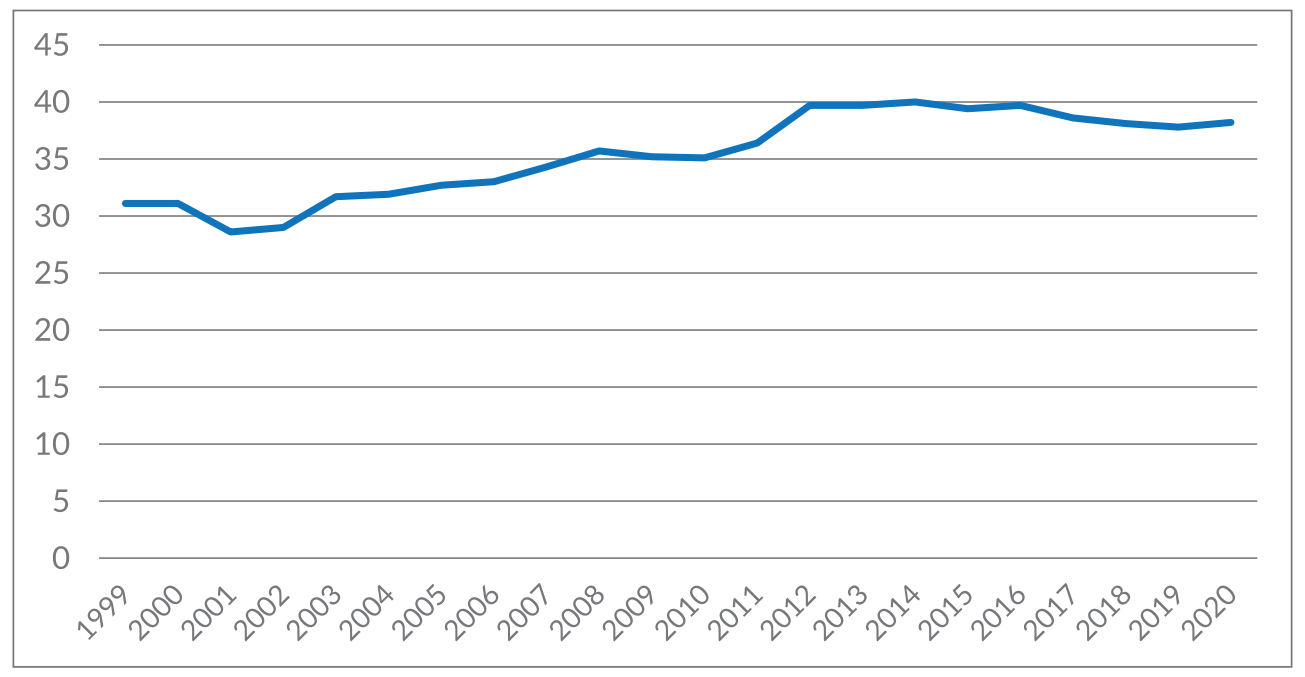

Source: World Bank Indicators

Inequality in the period under study decreased and fell (Figure 1). From the data collected for this study, the mean for inequality in 2015 was 0.34, while in 2017 fell to 0.33 . It means that, in general, the gap is decreasing, indicating that many districts experienced that gap becoming smaller. For example, Tanjung Balai, a district in North Sumatra province, had a Gini of 0.365 in 2015, falling to 0.278 . This district experienced a fall in Gini for about -0.086, which is relatively large. Figure 2 reveal that many districts experienced a fall in inequality. The median value of this change is -0.02 .

\section{Inequality and political process}

The basic assumption concerning narrowing down inequality is that income level forms individual preferences. In order to reduce inequality, the poor prefer to have deep government intervention. On the contrary, the rich favor less intervention in various policies. The logic to understand this situation is relatively simple. In a situation with no or less government intervention, the rich maintain their interests, whereas the poor may encounter problems gaining basic provisions. The rich can access these facilities 
such as education and health services through the market mechanism in private hospitals or schools. On the contrary, the poor have limited access to these provisions.

Having mentioned differences in preferences between the elite and the people, a discussion on democracy and inequality can be grouped into two camps. One camp believes that democracy and inequality have positive associations, whereas another group believes there are no relationships. Bollen \& Grandjean (1981) find that democracy has no effect of inequality. Sirowy \& Inkeles (1990) state that democracy could not reduce inequality. Deininger \& Squire (1996) find no significant correlation between democracy and inequality. Knutsen \& Weggman (2016) argue that most citizens, either in rich or poor countries or egalitarian or inegalitarian societies, do not consider progressive redistribution among democracy's most important features. In the postcolonial states, including Indonesia, the problems of redistributions are closely associated with the state capability to implement the programs instead of democracy (Slater et al., 2014).

Figure 2. Change of the Gini Coefficient 2015 to 2017

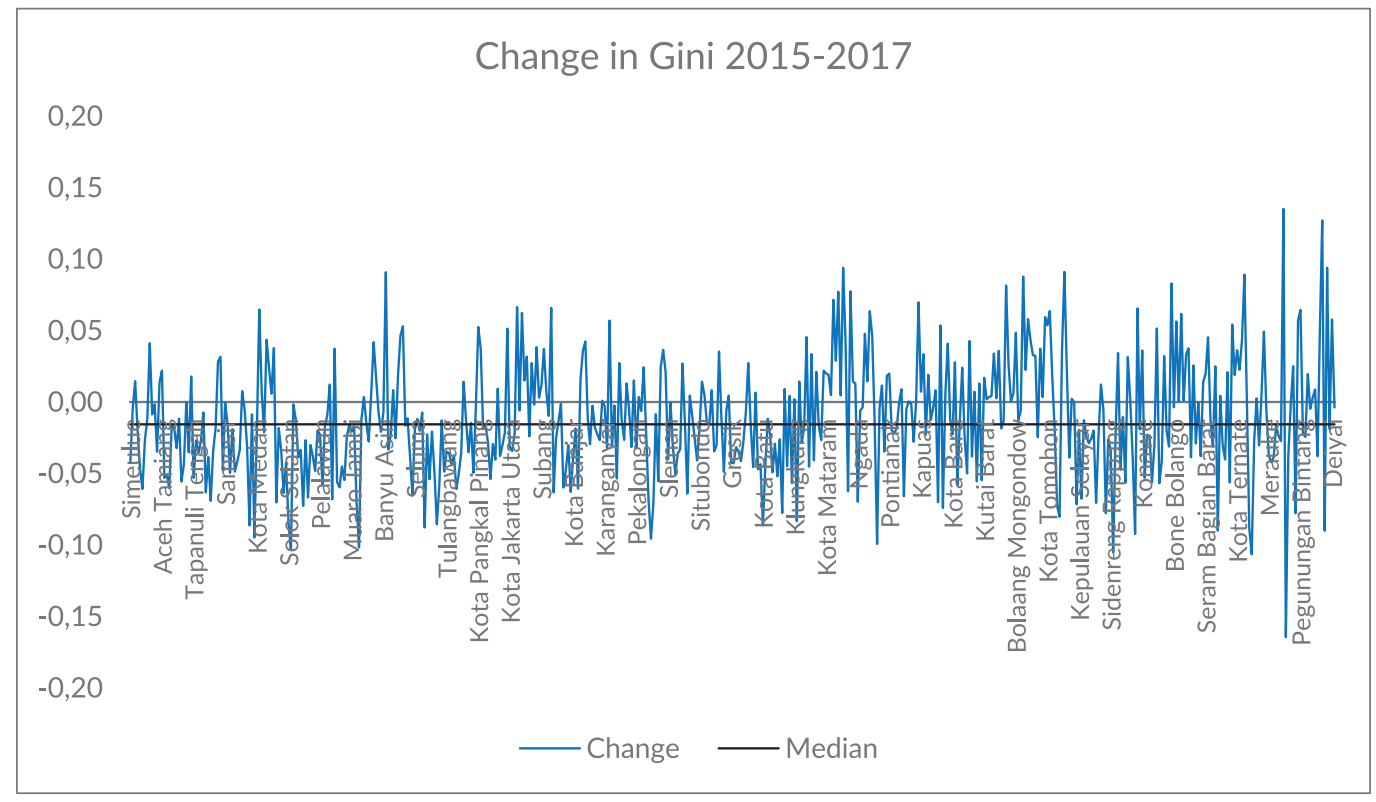

Source: Bappenas from BPS

Contrary to the previous opinion, an argument proposed by Acemoglu \& Robinson (2001; 2006) and Boix (2003) can be called a redistributive approach. Acemoglu and Robinson (2006) state that "democracy is usually not given by the elite because its values have changed. It is demanded by the disenfranchised as a way to obtain political power and thus secure a larger share of the economic benefits of the system." Boix (2003), Acemoglu \& Robinson (2006) focus on how economic inequality, the relative distribution of income or assets, influenced voters' demand for reallocation. Boix (2003), Acemoglu and Robinson (2006) base their arguments on the supposition that a dictator and the rich, the elite, have similar preferences, while the middle class and the poor demand an end to manipulation by the elite. They see that democracy could occur 
when the citizens can form a credible organization and present weight for opposition to the elite. Confronting credible pressure, the elite is pushed to allow democracy to run. Their arguments are not perfectly matching but suggest similar reasoning. Boix (2003) contends that a falling-off in inequality stimulates democracy. Acemoglu \& Robinson (2006) argue that democracy augments a decline in inequality through redistribution. Nevertheless, low inequality or high redistribution is predicted under democracy. In a similar line of argument, Acemoglu et al. (2019) provide evidence that democracy positively affects GDP per capita. They believe that improved reallocation and the end of manipulation would be possible.

Other writers argue on similar lines to Boix and Acemoglu \& Robinson's. Perotti (1993) finds an association between the political process and redistribution. Perotti (1993) contends, "the lower class will invest in education if the median voter has an incentive to enact enough redistribution." Scheve \& Stasavage (2009) claim that the political process has a little causal effect on inequality in the long run. They mention that political factors do matter, but not in the often suggested way (Scheve \& Stasavage, 2009). Gradstein \& Milanovic (2004) proved that democracy supports redistribution. Milanovic (2016) argues that democracy and redistribution correlate because economic decisions have political implications.

Those arguments, as mentioned earlier, seem to follow and modify Meltzer \& Richard (1981), who offer a foundational study of inequality and democracy. Meltzer \& Richard formulated the alleged mismatch of democracy and property into a formal theory of rational expectations about electoral politics. A majority of voters receive less than average income. Therefore, there are more poor people than rich people. It would create a situation where under-average income prefers to raise taxes on that above-average income; therefore, democracy should consistently engender force for redistribution. The force for redistribution would enlarge with growing inequality. The logic is simple: as the rich grow richer than others, the poorer median voter would benefit more by prolonging to lift taxes. Therefore, outcomes of political struggle are a function of the preferences of the median voter, who prefer high taxes and substantial redistribution to poor people like themselves (Acemoglu \& Robinson, 2006; Boix, 2003). On the contrary, the rich prefer no taxes and no redistribution. In high-income countries, these writes concentrate on tax policies as a vehicle for redistribution, while in a middle-income country such as Indonesia, redistributive policies take various forms of direct assistance to the poor people.

The argument, as mentioned earlier, for inequality and democracy mainly analyzes high-income countries in North America and Western Europe. Haggard \& Kaufman (2008) provided one of the most comprehensive assessments of social policy in developing countries of Latin America, East Asia, and Eastern Europe. They underscore the affirmative consequences of democracy on social policy. Their finding is derived from the median voter theorem. They recognize the force of the lower-income groups that entered the electoral arena after democratization. This finding parallels the conclusion drawn by Meltzer \& Richard (1981); therefore, they have a similar line argument to that of Acemoglu \& Robinson (2006). 
This paper contends that democracy provides an impetus for the incumbent government to address crucial issues such as a social policy to satisfy most voters. In order to earn legitimacy of both political and economical, the incumbent government had adopted social policies that could reduce or solve a range of pressing social issues, one of which is inequality. In essence, this paper mentions that the democratic process, such as the presidential election, would put critical pressure on the competing candidates to implement a range of social policies when they are elected, gain votes from the voters, and most of the voters are in the lower-income group. By looking at the composition of the voters who are mostly in the low-income category, the competing candidates are pressured to address social policies to reduce the gap between the rich and the poor people. In this sense, the incumbent has benefited as s/he already implemented a range of social policies to reduce inequality to avoid open conflict between the rich and the poor.

Furthermore, the redistributive social policies provide access to the poor people through various provisions such as healthcare and education. As a result, the incumbent would gain legitimacy from the voters. This paper is in line with the arguments proposed by Boix (2003), Acemoglu \& Robinson (2006). In the context of the Indonesian economy, inequality, especially after the economic recovery process since 2000, tended to increase. The inequality reached its peak in 2014 and became an essential issue for the government.

\section{Measuring the Gap: Gini coefficient}

For three years in 1999, 2002, and 2003, the poorest $40 \%$ share was more than 20 $\%$ (BPS 2003). BPS reported that in 2003, the level of inequality increased (expenditure distribution started to worsen). The report mentions the portion spent by the $40 \%$ of the lowest income population declined from $21.66 \%$ in 1999 to $20.92 \%$ in 2002; and $20.57 \%$ in 2003. The Gini coefficient for those years also improved from 0.31 in 1999 to 0.33 in 2002. After the Asian financial crisis in 1997 that also hit Indonesia, the poverty level increased dramatically, Gini coefficient also fell. Almost everyone was affected by the crisis, but the richest segment was hit hardest. When Indonesian economic recovery started to take form, aided by the commodity boom and the global financial crisis, the Gini rose.

However, the increase of the Gini at the beginning of the 2000s was not as big as that of in the 2010s. After the country recovered from the Asian financial crisis and the global crisis, Indonesia's real GDP per capita grew annually at an average of $5.4 \%$ between 2000 and 2014 (World Bank, 2016). The World Bank's report revealed that this growth helped many to pull out from poverty, but at the same time, creating a strong middle class. The middle class mostly enjoyed this growth. Between 2003 and 2010, the richest $10 \%$ consumption per capita grew more than $6 \%$ per year, while the poorest of $40 \%$ only grew at less than $2 \%$ (World Bank, 2016). Therefore, it would not be a surprise when Gini increased dramatically from 0.30 in 2000 to 0.41 in 2014, recorded as the highest in Indonesian history. In order to tackle the inequality, 
the central government aimed at reducing the gap between from 0.41 to 0.36 by year 2019 (Simangunson \& Kuang-Hui, 2018).

After explaining inequality in the previous sub-section, this paper poses a question: Does it find that inequality is associated with the Jokowi's votes as the incumbent? This study shows that it does. This study presents the relationship between the 2015-2017 change of inequality and Jokowi's presidential vote shares in 2014-2019. This study looks at the change in inequality between 2015 and 2017 because Jokowi's first term as the president passed these periods. More importantly, as mentioned above, the country had experienced the highest record for inequality in 2014. Therefore it is necessary to evaluate Jokowi's government to address this gap as an economic and political issue. Figure 3 shows strong evidence that change in inequality benefited Jokowi. The districts that experienced a fall in inequality were considerably more likely to vote for Jokowi in the 2019 election.

Figure 3. Jokowi vote shares 2014-2019 and Gini change 2015-2017

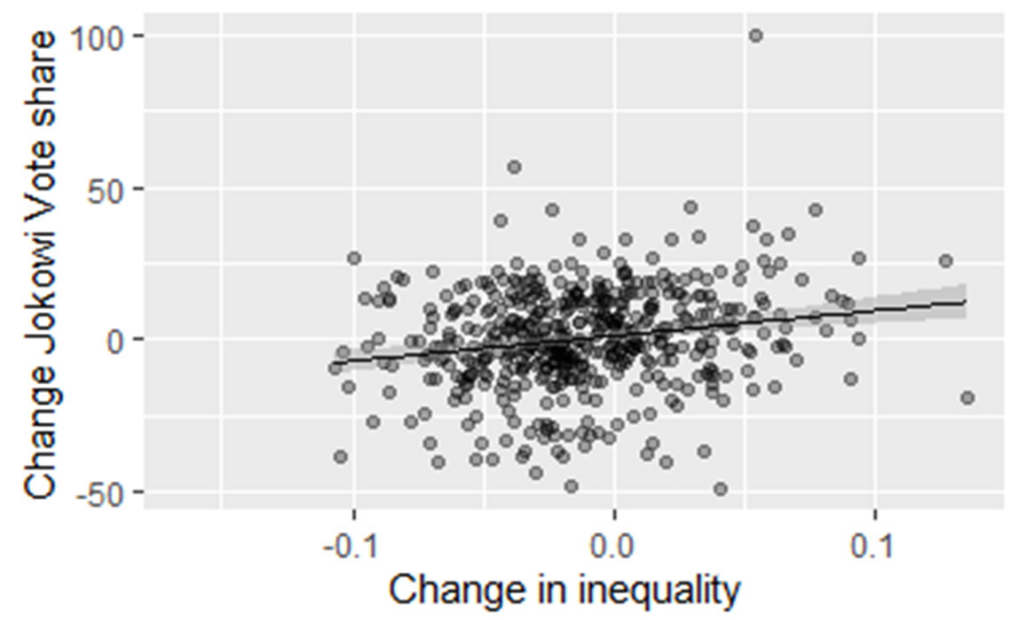

\section{METHODS}

This study employs Jokowi's vote share in 2019 in each district as the dependent variable is. The estimation model is as follows:

$$
\begin{aligned}
& \mathrm{JKWVote}_{\mathrm{i} 2019}=\beta_{0}+\beta_{1} \text { JKWVote }_{\mathrm{i} 2014}+\beta_{2} \Delta \mathrm{Gap}_{\mathrm{i} 2015-2017}+\beta_{3} \mathrm{Javanese}+\beta_{4} \text { Muslim } \\
& +\gamma \text { Controls }_{\text {i2014-2018 }}+\varepsilon
\end{aligned}
$$

The estimation model includes Jokowi vote shares in the 2014 presidential election to look at the various tendencies of the districts to vote for Jokowi. By adding the vote shares in 2014, this study is calculating a flexible valuation model of change in Jokowi's vote share between 2014 and 2019 (Finkel, 1995). This study is interested in coefficient of $\beta_{2}$. It captures the impact of inequality on the variation in Jokowi vote shares. The estimation model is following Healy \& Lenz (2017) and Finkel (1995). Healy \& Lenz (2017) employ panel data of two elections in the US: 2004 and 2008, and they place the election 2004 as one of the independent variables. They implemented the statistical method as explained by Finkel (1995). 
This paper modified Healy \& Lenz's (2017) estimation model. This paper adds social cleavages proportion of Muslim and Javanese as independent variables. This paper is considering that identity politics tainted the 2019 presidential election. Therefore, it is necessary to include social cleavages as variables that capture the phenomenon. Unlike Healy \& Lenz (2017), who study loan delinquencies as their primary variable of interest to understand voting and local economics, this present study assesses inequality as the primary variable. This study uses control variables to see the consistency of inequality in three estimations. The estimations also look at another economic variable which relation to voting.

$J K W$ votes 2019 and 2014 are voting share data for Jokowi and Jusuf Kalla in 2014 and Jokowi and Maruf Amin in 2019 at the district level. This paper uses two data points as Jokowi was the incumbent for the 2019 presidential election. Gap 2015-2017 is a change of inequality from 2015 to 2017 at the district level measured by the Gini coefficient. Javanese is a proportion of Javanese at the district level. Muslim is a proportion of Muslims at the district level. Some control variables are poverty, which measures the proportion of poor people at the district level; unemployment measures open at the district level in August each year. Poverty 2014-2018 measures change of poverty proportion in percentage at the district level. Unemployment 2014-2018 measures unemployment changes from 2014 to 2018 at the district level. This study employs two variables, poverty, and unemployment, to evaluate how voters respond to economic conditions. The strategy adopted by this paper is to look at the change in poverty and unemployment from 2014 to 2018. Data for this paper is collected from various sources. The data are at district level. Votes data for the presidential election are provided by the KPU. Some data are collected from the Bappenas site: adjusted per capita expenditure, unemployment and poverty. Bappenas data is collected from BPS. Javanese and Muslim data are from the census in 2000. Some control variables are also from the BPS as published by the Bappenas.

\section{RESULT AND DISCUSSION}

It is necessary to report the result of estimations in Table 1 . Model 1 reports that Jokowi shares in 2014, change of Gini coefficient from 2015 to 2017, the proportion of Javanese are positive and significant, and only proportion of Muslims in the districts is negative and significant. Changes of Gini have a coefficient of 0.41 , and it is relatively high in the real world. Jokowi vote shares in 2014 have a coefficient of 0.51 , a proportion of Javanese 0.31 , and a proportion of Muslim -0.46. His vote shares can explain the Jokowi vote shares increase in 2014, Gini, and proportion of Javanese at the district level.

Jokowi vote shares decreased were the proportion of Muslims in the district increased. In contrast, the proportion of Muslims can explain his decreased vote shares at the district level. This paper employs model 4, which adopted instrumental variables to check the possibility of endogeneity. The instrumental variable for model 4 is dummy Java were 1 for Java and 0 for other. The estimation result for model 4 is relatively similar to models 1,2 , and 3 , with a very small change in the coefficient of independent 
variables. The Muslim proportion in those models has relatively much bigger changed than other independent variables. In general, the estimation result from models 1, 2, and 3 are robust.

The concern variable of this paper is Gini, and its behavior is relatively consistent in models 1, 2, 3, and 4. The coefficient for Gini in model 1 is 0.41 and for model 2 is 0.41 , model 3 is 0.42 , and model 4 is 0.45 , all at a significant level of 0.00 . The coefficients of Gini tend to increase a little from model 1 to model 4. These changes result from the inclusion of control variables in models 2,3 , and model 4 because of the adoption of the instrumental variable. However, the most important findings from this paper are that Gini behave consistently to explain the Jokowi vote shares in 2019.

Table 1. Estimation Result by Ordinary Least Squares (OLS)

Dependent variable Jokowi vote shares in 2019.

\begin{tabular}{|c|c|c|c|c|}
\hline Level of Analysis: districts & (Model 1) & (Model 2) & (Model 3) & $\begin{array}{r}\text { Model } 4 \\
\text { (Instrumental } \\
\text { Variable) }\end{array}$ \\
\hline \multirow[t]{2}{*}{ Jokowi Votes 2014} & $0.51517^{* * *}$ & $0.51373^{* * *}$ & $0.50992^{* * *}$ & $0.42320^{* * *}$ \\
\hline & $(0.03452)$ & $(0.03449)$ & $(0.03460)$ & $(0.04022)$ \\
\hline \multirow[t]{2}{*}{ Gini 2015-2017 } & $0.41735^{* * *}$ & $0.41859^{* * *}$ & $0.42698^{* * *}$ & $0.45230^{* * *}$ \\
\hline & $(0.11817)$ & $(0.11804)$ & $(0.11815)$ & $(0.12490)$ \\
\hline \multirow[t]{2}{*}{ Javanese } & $0.31346^{* * *}$ & $0.31005^{* * *}$ & $0.30972^{* * *}$ & $0.42247^{* * *}$ \\
\hline & $(0.01521)$ & $(0.01537)$ & $(0.01537)$ & $(0.02721)$ \\
\hline \multirow[t]{2}{*}{ Muslim } & $-0.46999^{* * *}$ & $-0.47415^{* * *}$ & $-0.47307^{* * *}$ & $-0.53088^{* * *}$ \\
\hline & $(0.01881)$ & $(0.01900)$ & (0.01901) & $(0.02299)$ \\
\hline \multirow[t]{2}{*}{ Poverty 2014-2018 } & & -0.47296 & -0.47652 & -0.11135 \\
\hline & & $(0.32485)$ & $(0.32495)$ & $(0.35048)$ \\
\hline \multirow[t]{2}{*}{ Unemployment 2014-2018 } & & & 0.25553 & 0.26383 \\
\hline & & & $(0.21686)$ & $(0.22909)$ \\
\hline \multirow[t]{2}{*}{ Years of school 2014-2018 } & & & -1.74831 & -1.34660 \\
\hline & & & $(1.85922)$ & $(1.96557)$ \\
\hline \multirow[t]{2}{*}{ Constant } & $55.95781^{* * *}$ & $56.06617^{* * *}$ & $57.10717^{* * *}$ & $63.69653^{* * *}$ \\
\hline & $(2.87216)$ & (2.86969) & (2.99049) & (3.40699) \\
\hline Observation & 497 & 497 & 497 & 497 \\
\hline R square adjusted & 0.8272 & 0.8276 & 0.8277 & 0.8078 \\
\hline
\end{tabular}

Table 1 informs that economic variables such as changes in unemployment and poverty are insignificant and have positive signs. A study by other researchers found that unemployment in the long term positively affects income inequality (Agusalim \& Pohan, 
2018), and this study does not want to reject such a conclusion. Instead, this study takes a different path, and it evaluates the effect to vote shares in a presidential election as it is found in this study. Table 1 informs that education is also not significant with a positive sign. The behavior of changes in unemployment and poverty is consistent with a sense that they cannot explain vote shares for Jokowi in 2019, even though the positive signs are in line with the expectation. The changes in poverty and unemployment are expected to impact Jokowi vote shares in 2019, but the estimation results find they are not significant. The result of changes in unemployment and poverty in model 4 is also not significant with positive signs.

The estimations result in Table 1 exhibit that redistributive policies, as indicated by the change of Gini, fashioned the presidential election result. The relative robust effect of Gini, which is a product of various redistributive policies articulated and executed by both the central and local government, has exhibited that the district level voters hold the central government answerable for events outside its power (Healy \& Malhotra, 2009). Indeed, in the Indonesian context, the local governments depend on the central government's transfer of various funds (Amalia, 2018). Therefore, it would not surprise voters if they believe that the central government plays a significant role in redistributive policy.

The finding of this paper puts relevance on the redistributive policy, but the 2019 presidential election result indicates that identity politics is also at play. This verdict is consistent with Thomas Pepinsky's (2019) conclusion. While acknowledging Pepinsky's finding, this paper underlines redistributive policy. This paper underlines voting based on economic calculation. In the broader context, this paper underlines the relevance of redistributive policies. The voters would evaluate the past performance of the incumbent's capacity to meet the voters' expectation on mitigating the widening gap between the rich and the poor people. The finding of this paper is in line with that of Meltzer \& Richard (1981) Acemoglu \& Robinson (2006) arguments' which connects the redistributive policies to the political rationale and particularly to electoral incentives. They mention that in democracy, office-seeking policy-makers make public policies to maximize their chance of securing the election. Politicians count the preferences of a majority of voters.

How to understand these differences in economic variables to explain Jokowi vote shares in 2019? Reducing poverty and unemployment have been the primary concern of the Indonesian government since the New Order regime. After the fall of the New Order regime, the following governments are also put serious attention to reducing poverty and unemployment. These are macroeconomics indicators which always be watched by the governments. Therefore, poverty and unemployment could be maintained at a low level. The economic recovery that has taken place since 2000 up to 2004 was able to reduce the number of poverty and unemployment due to the economic crisis that hit the country in 1997-1998. While economic recovery was able to reduce poverty and unemployment rates, the inequality tended to increase until 2014. During the 1997-98 financial crisis, poverty increased dramatically, but the ratio fell because everyone was affected. However, when the economic recovery started to take shape, and the economy grew, the gap between 
the rich and the poor widened. The Gini has increased from 0.30 in 2000 to 0.41 in 2014, the highest Indonesian history (World Bank, 2018). One possible explanation for the increase in inequality may be the growth of the middle class.

The report mentions that several factors are responsible for the increasing gap between the rich and the poor. These factors are assets, income, consumption, and investment (World Bank, 2016). The report contends that high inequality may slow economic growth if poorer people cannot invest in their child development. It also argues that high-level inequality would increase the social cost, which provided an impetus for conflicts at the societal level. When people perceive that the gap between the rich and the poor is widening, income and wealth will open conflict. In short, a high level of inequality in Indonesia in income and wealth may hinder economic growth and potentially lead to open conflict in society. Facing this rising severe divide, both Yudhoyono and Jokowi governments adopted social policies to mitigate the widening gap. However, there were sentiments of discontent with the Yudhoyono administration because of the increase of inequality (Aspinal et al., 2015) as it was experiencing an increase in its decade rule. Therefore, the next 2014 and 2019 presidential elections were political competitions for a candidate that the voters believe could address the gap.

The first Jokowi administration addressed the widening gap by adopting several policy measures such as reducing stunting incidences, reducing the poverty rate, offering job opportunities, reducing the gap between the rich and poor, and strengthening industry for the SMEs. ${ }^{3}$ Relevant to the finding of this paper is Jokowi's government's effort to reduce the gap between the rich and poor. When Jokowi was installed as president in 2014, he adopted a vital policy that intended to reduce poverty and reduce the gap between the rich and poor: eliminated the subsidy for gasoline (TNP2K 2019). Jokowi argues that the subsidy for gasoline was mostly benefited the middle class instead of the poor people. Most importantly, he enlarged the social protection program for the poor.

This paper addresses the programs that are relevant to reducing inequality in Indonesia. The social protection programs have been targeted at children and low-income families. These programs were non-food assistance (Bansos Rastra); conditional cash transfer (Program Keluarga Harapan, PKH); educational cash transfer (Kartu Indonesia Pintar, KIP), food assistance (Sembako), and social insurance (Jaminan Kesehatan Nasional, Jaminan Kecelakaan Kerja). PKH aimed at 10 million poor households in 2017-2018 (TNP2K, 2019). Bansos Rastra was the biggest scheme for 15.6 million poor family with investment at around $0.18 \%$ of GDP (TNP2K 2019, 49). Other schemes implemented by Jokowi were family welfare deposit program (program simpanan keluarga sejahtera, PSKS) as compensation for elimination of the gasoline subsidy; family hope program (program keluarga sejahtera, PKH); Indonesian health card (Kartu Indonesia Sehat, KIS); and Indonesian Smart Card (Kartu Indonesia Pintar, KIS). PSKS was targeted at 1 million beneficiaries who received 200,000 IDR for 5 months. Perhaps, these policies work to

\footnotetext{
${ }^{3}$ https://indonesiabaik.id/infografis/uapaya-atasi-ketidakmerataan
} 
reduce inequality. Therefore, the government pursued policies that work to bridge the gap, as Przeworksi (2012) and Landa \& Kapstein (2001) discussed.

During his first term as president, Jokowi enlarged the social protection program, which mainly targeted the poor, and as a result, inequality, as indicated by the Gini, started to decrease. Improvement of social protection programs has contributed to the decrease of the Gini from 39.2 to 38.0 in 2019 (TNP2K 2019, 78). The change indicates that even very small there was a positive sign that implementing various redistributive policies could reduce the Gini. As mentioned above, the government's efforts for a substantial redistributive policy is a political process to reduce inequality. Scheve \& Stasavage (2009) contended that political factors do matter. They believe that political decisions for redistribution would require a long-time process. Their conclusion is accurate, and this paper does not intend to reject it. However, in a presidential contestation environment, as this study claims, the voters tend to vote for a candidate that can reduce the gap. The finding of this study is closer to those of Gradstein \& Milanovic (2004), who proved that democracy supports redistribution, and Milanovic (2016) contends that democracy and redistribution are associated because economic decisiveness has political insinuations.

The government efforts to reduce inequality benefited Jokowi's administration. It indicates that various social protection programs devised under the Jokowi administration worked and benefited the poor people most importantly. The poor people had access to social insurance, education, and health facilities. It is important to note that these social protection programs have weaknesses such as inclusion and exclusion errors or simply mistargeting. However, these weaknesses are beyond the scope of the present study. The Jokowi administration in 2014-2019 tried to improve the provision of the social protection program through various policies, and one of them should be the improvement of the database for poor people. The voters seemed to perceive that the government under Jokowi was responsive to the widening inequality gap. Most importantly, the voters saw that the Gini declined in 2019 compared to that of 2014. The decline of Gini might not be very big, but there was a tendency to decline.

The regions that reduced the gap between the rich and the poor people tended to vote for Jokowi. It means that the economic policy that Jokowi implemented in the first term to reduce inequality worked for him. This finding is very different from those of Iversen \& Soskice (2006) as they study democracy and redistributive policies in developed nations. While the finding of this paper underlines that the government policies to reduce inequality could determine the outcome of the election, it is relevant to note here that the gap between the rich and the poor people is still relatively high. In 2014 the richest $10 \%$ of Indonesian consumed as much as the poorest $54 \%$ (World Bank, 2016).

\section{CONCLUSION}

This study finds that inequality has relevant implications for the democratic process. Indonesia's 2019 presidential election highlighted the relevance of redistributive policies to gain votes. This study aims at understanding vote based on economic consideration 
at the district level. In the 2019 election in which Jokowi was incumbent, the voters at the district level assessed his capacity to reduce the widening gap between the rich and the poor people. This study unveils that social policies could also explain the result of the presidential election that the incumbent government has introduced. Jokowi's victory can be elucidated to redistributive policies, highlighting the relevance of the government efforts to reduce inequality. Thus, the district-level voters as a group were happy with Jokowi's performance in his first term to address inequality.

The finding of this paper implies that the government policies to reduce inequality resonate with the voters, and the government has incentives to continue these policies. This study shows that the voters can assess government policies, which signifies that these policies impact the voters. This finding in voters' response to redistributive policies reveals a good prospect for the future of democracy in Indonesia. Identity politics also drove the presidential election. Therefore, politicians would have a huge incentive to mobilize primordial sentiments such as religious or ethnic identity. The outcome of the elections, which operated on primordial sentiments, would direct deep societal division. On the contrary, if the voters base their judgment on economic factors, in this case, inequality, the competing candidates would likely consider the economic policies that satisfy the voters. An attractive puzzle for the future democracy in this country is whether the voters choose the presidential candidate that offers better economic policies to improve their welfare.

\section{REFERENCES}

Acemoglu, D., \& Robinson, J. (2001). A Theory of Political Transitions. American Economic Review, 91(4), 938-963.

Acemoglu, D., \& Robinson, J. (2006). Economic Origins of Dictatorship and Democracy. Cambridge University Press, New York.

Acemoglu, D., Naidu, S., Restrepo, P., \& Robinson, J. A. (2019). Democracy Does Cause Growth. Journal of Political Economy, 127(1), 48-97.

Agusalim, L., \& Pohan, F. S. (2018). Trade Opennes Effect on Income Inequality: Empirical Evidence from Indonesia. Signifikan: Jurnal Ilmu Ekonomi, 7(1), 1 - 14. https://doi.org/10.15408/sjie.v7i1.5527.

Amalia, F. (2017). Flypaper Effect of Regional Expenditures and It's Impact to Regional Inequality, Significant: Jurnal Ilmu Ekonomi, 6(1), 125-138. https://oi.org/sjie.v6i1.3293,

Aspinall, E. (2015). Inequality and democracy in Indonesia. Retrieved from: https://kyotoreview. org/issue-17/inequality-and-democracy-in-indonesia/, accessed 17 September 2020

Aspinall, E., Mietzner, M., \& Tomsa, D. (2015). The Yudhoyono Presidency: Indonesia's Decade of Stability and Stagnation. Institute of Southeast Asian Studies, Singapore.

Boix, C. (2003). Democracy and Redistribution. Cambridge University Press, New York.

Bollen, K. A., \& Grandjean, B. D. (1981). The Dimension(s) of Democracy: Further Issues in The Measurement and Effect of Political Democracy. American Sociological Review, 46(5), 651-659. 
BPS. (2003). Statistical Yearbook of Indonesia 2003. Jakarta: BPS

Dartanto, T., Moeis, F. R., Otsubo, S. (2020). Intragenerational Economic Mobility in Indonesia: a Transition from Poverty to The Middle Class 1993-2014. Bulletin Indonesian Economic Studies, 56(2), 193-224. https://doi.org/10.1080/00074918. 2019.1657795 .

Deininger, K., \& Squire, L. (1996). A New Data Set Measuring Income Inequality. World Bank Economic Review, 10(3), 565-91.

Finkel, S. E. (1995). Causal Analysis with Panel Data. Sage Publication, New Jersey.

Gradstein, M., \& Milanovic, B. (2004). Does liberte` = Egalite'? A Survey of the Empirical Links between Democracy and Inequality with Some Evidence on the Transition Economies. Journal of Economic Surveys, 18(4), 516-537

Haggard, S, \& Kaufman, R. R. (2008). Development, Democracy, and Welfare States: Latin America, East Asia and Eastern Europe. Princeton University Press, Princeton.

Healy, A., \& Lenz, G. S. (2017). Presidential Voting and The Local Economy: Evidence from Two Population-Based Data Sets. The Journal of Politics, 79(4). https://doi. org/10.1086/692785.

Healy, A., \& Malhotra, N. (2009). Myopic Voters and Natural Disaster Policy. American Political Science Review, 103(3), 387-406. https://doi.org/10.1017/S0003055409990104.

Iversen, T., \& Soskice, D (2006). Electoral Institutions and the Politics of Coalitions: Why Some Democracies Redistribute more than Others, American Political Science Review, 100(2), 165-181

Kawamura, K. (2019). Politics of Inequality in Indonesia: Does Democracy Matters? In Keiichi, T., and Todo, Y. (eds.) Emerging State at Crossroads. Springer, Singapore.

Knutsen, C. H., \& Wegmann, S. (2016). Is Democracy About Redistribution? Democratization, 23(1), 164-192.

Landa, D., \& Kapstein, E. B. (2001). Inequality, Growth, and Democracy. World Politics, 53, 264-296

Maipita, I., \& Wahyudi, S. T. (2017). Income Distribution and Inequality in Indonesia: Study on Middle Class Household, Jurnal Ekonomi Pembangunan, 18(1), 131-141. https://doi.org/10.23917/jep.v18i1.3974.

Meltzer, A. H., \& Richard, S. F. (1981). A Rational Theory of The Size of Government. Journal of Political Economy, 89, 914-27.

Milanovic, B. (2016). Global Inequality: A New Approach for The Age of Globalization. Belknap Press, Massachusetts.

Muhtadi, B., Warburton, E., \& Dewayanti, A. (2019). Perceptions of Inequality in Indonesia: A Matter of Partisan Politics? ISEAS Perspective, 10

Pepinsky, T. (2019). Islam and Indonesia’s 2019 Presidential Election. Asia Policy, 14(4), 54-62.

Perotti, R. (1993). Political Equilibrium, Income Distribution, and Growth. The Review of Economic Studies, 60(4), 755-776. https://doi.org/10.2307/2298098. 
Przeworski, A. (2012). Democracy, Redistribution, and Equality. Brazilian Political Science Review, 6(1), 11-36

Sato, Y. (2019). Reemerging Developmental State in Democratized Indonesia. In Takagi, Y., Kanchoochat, V., \& Sonobe, T. (eds.), Developmental State Building: The Politics of Emerging Economies. Springer, Singapore. https://doi.org/10.1007/978-981-132904-3-4.

Scheve, K., \& Stasavage, D. (2009). Institutions, Partisanships, and Inequality in The Long Run. World Politics, 61(2), 215 - 253

Simangunson, D., \& Kuang-Hui, C. (2018). Inequality and Economic Growth in Indonesia in the 2000s. Signifikan: Jurnal Ilmu Ekonomi, 7(2), 201-212. https:// doi.org/10.15408/sjie.v7i2.6177.

Sirowy, L., \& Inkeles, A. (1990). The Effects of Democracy on Economic Growth and Inequality: a Review. Studies in Comparative International Development, 25, 126-57.

Slater, D., Smith, B., \& Nair, G. (2014). Economic Origin of Democratic Breakdown? The Redistributive Model and the Postcolonial State. American Political Science, 12(2), 354-374. https://doi.org/10.1017/S1537592714000875.

Tadjoeddin, M. Z., Yumna, A., Gultom, S. E., Rakhmadi, M. F., \& Suryahadi, A. (2020). Inequality and Violent Conflict from Selected Provinces in Post-Soeharto Indonesia. Journal of the Asia Pacific Economy, 26(3), 1-22 https://doi.org/10.1080/13547860. 2020.1773607

TNP2K. (2019). Menanggulangi Kemiskinan dan Menurangi Kesenjangan melalui efektivitas kebijakan dan Program: Laporan Pelaksanaan Tugas Sekretariat TNP2K 2015-2019. TNP2K, Jakarta.

Widyanti, R. D. (2018). Wage Inequality and Return to Education in Indonesia: Quantile Regression Analysis. Signifikan: Jurnal Ilmu Ekonomi, 7(1), 27- 44. https://doi. org/10.15408/sjie.v7i1.6071.

World Bank. (2016). Indonesia's Rising Divide. World Bank, Washington DC.

World Bank. (2018). Indonesia Economic Quarterly: Urbanization for All. World Bank, Washington, DC. 